\title{
Interactions between invertebrate and microbial communities in decomposing camphor and Masson pine litter varied with seasonal rainfall
}

\author{
Jun $\mathrm{Li}^{1}$, Chenhui Chang ${ }^{2}$, and Wanqin Yang ${ }^{1}$ \\ ${ }^{1}$ Taizhou University \\ ${ }^{2}$ Vrije Universiteit Amsterdam
}

October 29, 2020

\begin{abstract}
To reveal the changes in the interactions between invertebrate and microbe in decomposing litter along with seasonal rainfall, litterbags containing camphor (Cinnamomum longepaniculatum) and Masson pine (Pinus massoniana) litter were respectively in-situ incubated on the floor of Masson pine and camphor mixed plantations in October 2013 in subtropical region of China. Different mesh sizes of litterbags were used to control the access of the invertebrate. The invertebrates were collected by funnel method, and microbial communities were measured by phospholipid fatty acid (PLFA) method after collecting the litterbag samples in slightly rainy season (SRS), micro rainy season (MRS), early rainy season (ERS) and rainy season (RS) during 2-yr decomposition. We found that the abundance and structure of microbial and invertebrate communities varied sharply with seasonal rainfall and tree species. Invertebrate exclusion generally decreased all types of microbial biomasses (the total microbial biomass, fungal biomass and bacterial biomass, Gram-positive bacterial biomass and Gram-negative bacterial biomass) in Masson pine needle litter, but generally increased these types of microbial biomasses in camphor foliar litter at most time. Invertebrate exclusion decreased the mass loss rate of Masson pine litter, but increased the mass loss rate of camphor litter. In conclusion, the interactions between invertebrates and microbial communities are significantly controlled by litter quality and the seasonal rainfall pattern, which could significantly drive the decomposition process of leaf litter.
\end{abstract}

\section{Hosted file}

manuscript for LDD.pdf available at https://authorea.com/users/371187/articles/489606interactions-between-invertebrate-and-microbial-communities-in-decomposing-camphor-andmasson-pine-litter-varied-with-seasonal-rainfall 